\title{
Bank Capital Regulation and Soft Budget Constraints
}

\author{
Kenji Tsuji
}

Published online: 10 February 2015

(C) The Author(s), licensee International Atlantic Economic Society 2015

\begin{abstract}
This paper presents a model of soft budget constraints on firms where refinancing of poor projects is ex post inefficient when viewed in isolation, and analyzes how bank capital regulation affects the softness of firms' budget constraints. A firm is said to have a soft budget constraint if a bank allows the firm to continue to operate even when continuation is ex post inefficient. It is shown that bank capital regulation may induce soft budget constraints on firms because banks have an incentive to roll over loans made to poor firms in order to comply with the regulation. It is also shown that soft budget constraints are more likely to arise when the regulation is less strict, that is, when banks' minimum required capital ratios are lower. This paper also demonstrates that soft budget constraints may be more likely to arise under Basel III, that bank capital regulation may increase the probability of bank failures by inducing the soft budget constraint problem, and that the bank capital regulation of Basel I was one of the causes of soft budget constraints in the post-bubble period of Japan.
\end{abstract}

Keywords Bank capital regulation · Soft budget constraints · Credit crunch · Basel III

JEL Classification $\mathrm{G} 20 \cdot \mathrm{G} 30$

\section{Introduction}

This paper investigates how bank capital regulation affects the soft budget constraint problem. ${ }^{1}$ Du and Li (2007) argue that it is harder and less credible for countries with a larger fiscal capacity to commit to a hard budget constraint on banks because the ability of these countries to bail out failing banks is restricted by their fiscal capacity. Thus, Du and Li predict that governments with more abundant fiscal resources will impose stricter bank capital regulation to minimize efficiency losses from moral hazard that occur under

${ }^{1}$ The soft budget constraint problem originated with Kornai (1980).

K. Tsuji $(\bowtie)$

Graduate School of Economics, Osaka City University, 3-3-138 Sugimoto, 558-8585 Sumiyoshi-ku,

Osaka, Japan

e-mail: tsujiken@econ.osaka-cu.ac.jp 
soft budget constraints on banks. That is, they argue that bank capital regulation becomes an institutional solution to the problem of soft budget constraints on banks.

In contrast to Du and $\mathrm{Li}$ (2007), this paper focuses on soft budget constraints on firms, not on banks. It may be supposed that bank capital regulation prevents banks from refinancing poor projects and hardens the budget constraints of firms. However, this paper shows that bank capital regulation is one of the causes of soft budget constraints on firms.

In this paper, the definition of a soft budget constraint on a firm is as follows. A firm has a soft budget constraint if the lending bank allows the firm to continue to operate even when continuation is ex post inefficient. ${ }^{2}$ Dewatripont and Maskin (1995) have shown that soft budget constraints arise because the initial investment is sunk. In their model, refinancing that would be ex ante inefficient is ex post efficient due to sunk costs. This paper assumes ex post inefficiency in order to show that soft budget constraints arise not from sunk costs but from bank capital regulation. That is, in contrast to the models of Dewatripont and Maskin (1995) and Berglöf and Roland (1997), refinancing of poor projects is ex post inefficient when seen in isolation.

The analysis of this paper has some interesting results. First, bank capital regulation may induce soft budget constraints on firms. Second, soft budget constraints are more likely to arise when the regulation is less strict, that is, when banks' minimum required capital ratios are lower. Third, soft budget constraints are more likely to arise when the liquidation value of a project is smaller and the return from the project and its success probability are larger.

This paper is also related to the literature on financial institution failures. In the literature, many researchers, such as Barth (1991), Amos (1992), Cebula (1994, 2010), Litan (1994), and Chou and Cebula (1996), have examined factors behind financial institution failures. These factors include (1) economic conditions, such as the growth rate of gross product and the cost of funds; (2) bank financial conditions, such as capital ratios and charge-offs; (3) banking deregulation, which increases competition among banks and lowers the profitability of banks; and (4) monetary policy, such as high growth rates of money supply in a stagnant economy, that induces banks to make risky loans with low rates of return.

In comparison with the existing literature, this paper offers a new explanation for bank failures. Specifically, this paper suggests that bank capital regulation may increase the probability of bank failures by bringing about the soft budget constraint problem, which reduces the profitability of banks.

The rest of this paper is structured as follows. The next section describes the basic model. The third section analyzes bank behavior in the absence of bank capital regulation, and the fourth section analyzes bank behavior under binding bank capital regulation. The last section concludes with a summary and some implications.

\section{The Model}

Consider the following model where there are three dates, $t=0,1,2$, and three types of agents, namely, banks, firms, and the government. For simplicity, the risk-free market interest rates are certain and normalized to zero, and thus there is no discounting.

\footnotetext{
${ }^{2}$ See Mitchell (2002, pp.9-10) for a more detailed definition of soft budget constraints. Recent literature on the definitions and concepts of the soft budget constraints includes Luo (2014) and Vahabi (2012, 2014).
} 
All projects require one unit of capital at $t=0$. There are 2 types of projects, good and poor. Good projects generate return $R(>1)$ at $t=2$. Poor projects generate return $R$ with probability $q$ and a return of 0 with probability $(1-q)$ at $t=2$. If a project is terminated and liquidated at $t=1$, the liquidation value of the project is $L(0<L<1)$. I assume Eq. (1), which implies that it is more efficient to liquidate a poor project than to continue it, since its liquidation value exceeds its continuation value.

$$
q \cdot R<L
$$

From Eq. (1) and the assumption that $L<1$, poor projects are ex ante unprofitable. The firm is endowed with nothing and so must borrow one unit of capital from a bank at $t=0$ in order to undertake a project. The firm knows its own project type at $t=1$. As in Berglöf and Roland (1995) and other papers, it is assumed here that the firm obtains non-monetary, non-transferable unobservable private benefits if and only if the project is undertaken and continued until $t=2$.

The loan contract between the firm and the bank is made at $t=0$. As in Berglöf and Roland (1995, 1997), I assume that banks have all the bargaining power vis-à-vis firms and capture all the verifiable returns. I refer to a firm that undertakes a good (poor) project as a good (poor) firm. Suppose that a proportion $\alpha$ of borrowing firms are good firms and the remaining proportion $1-\alpha$ are poor firms. The bank knows the expected value, $\alpha^{\mathrm{e}}$, of $\alpha$ at $t=0$ and the actual value of $\alpha$ at $t=1$. For simplicity, I assume Eq (2), which implies that it is ex ante profitable for the bank to finance a firm at $t=0$.

$$
\alpha^{\mathrm{e}} \cdot R+\left(1-\alpha^{\mathrm{e}}\right) \cdot q \cdot R-1>0
$$

At $t=1$, the bank observes the type of each firm and then decides whether to continue or terminate the loans to that firm. Termination of the loan contract leads to the liquidation of the project. I assume that when loans to poor firms are continued, that is, when they are rolled over, they appear to be performing on the bank's balance sheet. ${ }^{3}$

The bank is financed by equity and deposits. While the initial stock of equity, $E_{0}$, is exogenously given and fixed, the bank can choose the amount of deposits $D_{0}$ at $t=0$. All deposits are covered by deposit insurance. Since depositors can always get their money back, they are indifferent to the bank's riskiness. As in Blum(1999), the bank bears the costs, $C(D)$, of deposits, $D$, with $C^{\prime}>0, C^{\prime \prime}>0$, and $C(0)=0$. This cost function means that when the bank wants to increase deposits, it has to pay higher interest rates to depositors, which reflects incomplete competition.

\section{Bank Behavior in the Absence of Bank Capital Regulation}

If bank capital regulation is not imposed, then the bank can choose its loan size by determining the amount of deposits. Since poor projects have a lower value in continuation than in liquidation, the bank terminates loans to poor firms and liquidates poor projects at $t=1$. The expected profit of the bank, $\prod_{\mathrm{B}}$, is given by

$$
\Pi_{B}=\mathrm{A}_{0} \cdot\left\{\alpha^{\mathrm{e}} \cdot R+\left(1-\alpha^{\mathrm{e}}\right) * L-1\right\}-C\left(D_{0}\right),
$$

\footnotetext{
${ }^{3}$ This assumption is also employed in Mitchell (2002).
} 
where $A_{0}$ denotes the total amount of bank loans at $t=0$. Differentiating Eq. (3) with respect to $A_{0}$ yields.

$$
\frac{\mathrm{d} \Pi_{\mathrm{B}}}{\mathrm{dA}_{0}}=\left\{\alpha^{\mathrm{e}} \cdot R+\left(1-\alpha^{\mathrm{e}}\right) \cdot L-1\right\}-\frac{\mathrm{d} C}{\mathrm{~d} D_{0}},
$$

since $D_{0}=A_{0}-E_{0}$. From the above assumptions with regard to $C$, the second-order condition for the bank's profit maximization is satisfied.

$$
\frac{\mathrm{d}^{2} \prod_{\mathrm{B}}}{\mathrm{dA}_{0}^{2}}=-C^{\prime \prime}<0
$$

Denoted by $\mathrm{A}_{0}^{*}$, the value of $A_{0}$ is such that the right-hand side of Eq. (4) is equal to zero. The bank is assumed to be risk neutral and so it maximizes its expected profits and chooses $\mathrm{A}_{0}^{*}$ as the optimal loan size. In the absence of bank capital regulation, it is clear that soft budget constraints are nonexistent since loans to poor firms will not be rolled over.

\section{Bank Behavior under Binding Bank Capital Regulation}

In this section, the capital ratio of the bank is constrained by the following regulation:

$$
\frac{\mathrm{E}_{\mathrm{i}}}{\mathrm{A}_{\mathrm{i}}} \geq c^{R},(i=0,1)
$$

where $E_{i}$ and $A_{i}$ denote bank capital and bank loans, respectively, at $t=i$ and $c^{R}$ represents the minimum required capital ratio determined by the government. If $c^{R}>$ $\mathrm{c}_{0}{ }^{*}$, then the regulation is binding at $t=0$, where

$$
c_{0}{ }^{*} \equiv \frac{\mathrm{E}_{0}}{\mathrm{~A}_{0}^{*}} .
$$

It is assumed that the regulation is binding at $t=0$, and so

$$
\frac{\mathrm{E}_{0}}{\mathrm{~A}_{0}}=c^{R}
$$

where $A_{0}<A_{0}^{*}$. If the bank liquidates poor projects at $t=1$, its capital at $t=1$ is given by

$$
\mathrm{E}_{1}=\mathrm{E}_{0}+\mathrm{A}_{0} \cdot(1-\alpha) \cdot(L-1) .
$$

From Eq. (9), I have

$$
\Delta \mathrm{E} \mathrm{E}_{1}-\mathrm{E}_{0}=\mathrm{A}_{0} \cdot(1-\alpha) \cdot(L-1)<0 .
$$

Liquidation of poor projects decreases bank loans since the loans to poor firms are terminated. If the bank continues all loans to good firms, then liquidating poor projects changes bank loans by

$$
\Delta \mathrm{A}^{\mathrm{c}}=-\mathrm{A}_{0} \cdot(1-\alpha) .
$$


From Eqs. (10) and (11), it follows that

$$
\frac{\Delta \mathrm{E}}{\Delta \mathrm{A}^{\mathrm{c}}}=1-L
$$

It is straightforward to show that if $\Delta \mathrm{A}<0$, then $\frac{\mathrm{E}_{1}}{\mathrm{~A}_{1}}=\frac{\mathrm{E}_{0}+\Delta \mathrm{E}}{\mathrm{A}_{0}+\Delta \mathrm{A}}<\frac{\mathrm{E}_{0}}{\mathrm{~A}_{0}}$ if $\frac{\Delta \mathrm{E}}{\Delta \mathrm{A}}>\frac{\mathrm{E}_{0}}{\mathrm{~A}_{0}} ; \frac{\mathrm{E}_{1}}{\mathrm{~A}_{1}}$ $=\frac{E_{0}}{A_{0}}$ if $\frac{\Delta E}{\Delta A}=\frac{E_{0}}{A_{0}}$; and $\frac{E_{1}}{A_{1}}>\frac{E_{0}}{A_{0}}$ if $\frac{\Delta E}{\Delta A}<\frac{E_{0}}{A_{0}}$, where $\Delta A \equiv A_{1}-A_{0}$. Hence, if $\frac{\Delta E}{\Delta A}>\frac{E_{0}}{A_{0}}$, then liquidating poor projects decreases the capital ratio. From Eqs. (8) and (12), if Eq. (13) holds, then the liquidation of poor projects decreases the capital ratio.

$$
1-L>c^{R}
$$

Equation (13) signifies that the liquidation of poor projects is more likely to decrease the capital ratio when the liquidation value of projects is smaller and banks' minimum required capital ratio is smaller, that is, when the regulation is less strict.

If Eq. (13) holds, then the liquidation of poor projects will cause the bank to violate the regulation at $t=1$ since the regulation is assumed to be binding at $t=0$. The penalty cost of violating the regulation is assumed to be prohibitive. Hence, the bank must either decrease loans to good firms or roll over loans to poor firms to maintain compliance with the regulation. ${ }^{4}$ Hereinafter, I assume that Eq. (13) is satisfied because it is clear that soft budget constraints do not arise when Eq (13) is not satisfied.

First, suppose that the bank decreases loans to good firms to satisfy the bank capital regulation. ${ }^{5}$ Since the bank determines $\Delta A$ so as to comply with the regulation, $\Delta A$ satisfies Eq. (14), for which the regulation is just binding.

$$
\frac{\Delta \mathrm{E}}{\Delta \mathrm{A}}=\frac{\mathrm{E}_{0}}{\mathrm{~A}_{0}}=\mathrm{c}^{R}
$$

Denoting the value for $\Delta \mathrm{A}$ that satisfies Eq. (14) by $\Delta \mathrm{A}^{\mathrm{t}}$, the following is obtained:

$$
\Delta \mathrm{A}^{\mathrm{t}}=\frac{\Delta \mathrm{E}}{\mathrm{c}^{\mathrm{R}}}=\frac{1}{\mathrm{c}^{\mathrm{R}}} \cdot \mathrm{A}_{0} \cdot(1-\alpha) \cdot(L-1) .
$$

From Eqs. (11) and (15), the bank must decrease loans to good firms by $A_{0} \cdot(1-\alpha)$. $\left(\frac{1-L}{\mathrm{c}^{\mathrm{R}}}-1\right)\left(=\left|\Delta \mathrm{A}^{\mathrm{t}}\right|-\left|\Delta \mathrm{A}^{\mathrm{c}}\right|\right)$. Hence, the cost to the bank of decreasing loans to good firms is $(\mathrm{R}-L) \cdot \mathrm{A}_{0} \cdot(1-\alpha) \cdot\left(\frac{1-L}{\mathrm{c}^{\mathrm{R}}}-1\right)$.

Second, suppose that the bank rolls over loans to poor firms in order to satisfy the regulation. The cost to the bank of rolling over loans to poor firms is $A_{0} \cdot(1-\alpha)^{*}\left(L-q^{*} R\right)$

\footnotetext{
${ }^{4}$ I assume that it is difficult for the bank to raise capital. This assumption is reasonable in the short term (Agénor and L. P. da Silva 2009). Also, "banks, like ordinary firms, are averse to issuing new equity in bad times; they are afraid of the negative inferences that might be drawn" (Blum and Hellwig 1995 p.742). Furthermore, "banks reduce lending more often than they recapitalize" (Hyun and Rhee 2011, p.323).

${ }^{5}$ Since information on whether a firm is good or poor is known only by the firm and its lending bank, it is difficult for a firm that cannot borrow from the informed bank to borrow from other banks.
} 
Hence, if Eq. (16) holds, then the bank will prefer to roll over loans to poor firms, and if Eq (16) does not hold, then the bank will prefer to decrease loans to good firms.

$$
(R-L) \cdot\left(\frac{1-L}{\mathrm{c}^{\mathrm{R}}}-1\right)>L-q \cdot R
$$

The above can be summarized as the following proposition.

Proposition 1: The bank rolls over loans to poor firms, if $(R-L) \cdot\left(\frac{1-L}{\mathrm{c}^{\mathrm{R}}}-1\right)>L-q \cdot R$; otherwise, it terminates all loans to poor firms and some loans to good firms.

If Eq. (16) holds, then each firm has a soft budget constraint because its lending bank allows the firm to continue to operate by rolling over loans, even when continuation is ex post inefficient. Proposition 1 implies that soft budget constraints arise when Eq. (16) holds, and hard budget constraints arise when it does not. Inspection of Eq. (16) shows that soft budget constraints are more likely to arise when the minimum required capital ratio $c^{R}$ is smaller, that is, when the regulation is less strict. This occurs because the bank is more likely to have an incentive to roll over loans to poor firms since each unit of equity becomes more valuable as $c^{R}$ decreases. It also shows that soft budget constraints are more likely to arise when the liquidation value $L$ is smaller and when the return $R$ from the project and its probability of success $q$ are larger. Furthermore, the proportion $\alpha$ of good firms does not affect the occurrence of soft budget constraints.

If the direction of the inequality in Eq. (16) is reversed, then the bank decreases loans to good firms, which will result in a credit crunch on them. By simple manipulation, Eq (16) can be rewritten as

$$
(1-L) \cdot\left(\frac{R-L}{(1-q) \cdot R}\right)>\mathrm{c}^{R} .
$$

From Eqs. (13) and (17), I have the following proposition.

\section{Proposition 2}

(1) If $0<c^{R}<(1-L) \cdot\left(\frac{R-L}{(1-q) \cdot R}\right)$, then soft budget constraints arise.

(2) If $(1-L) \cdot\left(\frac{R-L}{(1-q) \cdot R}\right)<c^{R}<1-L$, then a credit crunch on good firms arises.

(3) If $1-L \leq \mathrm{c}^{R}<1$, then neither soft budget constraints nor a credit crunch on good firms arises.

Proposition 2 implies that the occurrence of soft budget constraints or a credit crunch on good firms depends on the level of the minimum required capital ratio $c^{R}$.

\section{Conclusions}

This paper analyzed how bank capital regulation affects the softness of firms' budget constraints, and showed that bank capital regulation may induce soft budget constraints 
on firms. This occurs because banks have an incentive to roll over loans to poor firms in order to comply with the regulation. Additionally, soft budget constraints are more likely to arise when the regulation is less strict, that is, when banks' minimum required capital ratio is smaller. Furthermore, soft budget constraints are more likely to arise when the liquidation value of a project is smaller and the return from the project and its probability of success are larger. Finally, the occurrence of soft budget constraints or a credit crunch on good firms depends on the level of banks' minimum required capital ratio.

The liquidation value of projects, which is likely to reflect the value of collateral, tends to fall during a recession ${ }^{6}$ and in post-bubble periods. In such periods, setting banks' minimum required capital ratio to a low level may induce soft budget constraints, although it may reduce the risk that the loan supply is constrained by bank capital regulation. The countercyclical buffer of Basel III is set at a positive value in periods of excess credit growth and at zero in other periods. ${ }^{7}$ Since excess credit growth is usually observed in an economic boom, the buffer will likely be set at zero during a recession and in post-bubble periods, that is, banks' minimum required capital ratio will likely be set at a relatively low level during these periods. Hence, soft budget constraints may be more likely to arise under Basel III.

This paper also offers a new explanation for bank failures. That is, bank capital regulation may increase the probability of bank failures by inducing the soft budget constraint problem, which reduces the profitability of banks by causing them to retain non-performing loans.

Using micro data for Japan in the 1990s, Peek and Rosengren (2005) showed that troubled Japanese banks allocated credit to severely impaired borrowing firms with poor prospects. Watanabe (2010) found that, in Japan, losses of bank capital in FY 1997 led banks to reallocate lending to unhealthy industries with a higher concentration of non-performing loans. These empirical results imply that banks continued loans to poor firms, that is, that soft budget constraints on firms existed under the bank capital regulation of Basel I in the post-bubble period of Japan. ${ }^{8}$ These observed results are consistent with the conclusions of this paper.

Acknowledgments The author thanks an anonymous referee for helpful comments.

Open Access This article is distributed under the terms of the Creative Commons Attribution License which permits any use, distribution, and reproduction in any medium, provided the original author(s) and the source are credited.

\section{References}

Agénor P.-R. and L. P. da Silva. (2009). Cyclical effects of bank capital requirements with imperfect credit markets. Policy Research Working Paper No. 5067, World Bank.

Amos, O. M. (1992). The regional distribution of bank closings in the United States from 1982 to 1988. Southern Economic Journal, 58, 805-815.

Barth, J. R. (1991). The Great Savings and Loan Debacle. Washington, DC: A.E.I. Press.

\footnotetext{
${ }^{6}$ See Shleifer and Vishny (1992).

${ }^{7}$ See Basel Committee on Banking Supervision (2010a, b).

${ }^{8}$ Basel I was adopted in 1988 .
} 
Basel Committee on Banking Supervision. (2010a). "Basel III: A global regulatory framework for more resilient banks and banking systems." http://www.bis.org/publ/bcbs189.htm.

Basel Committee on Banking Supervision. (2010b). "Guidance for national authorities operating the countercyclical capital buffer.” http://www.bis.org/publ/bcbs187.htm.

Berglöf, E., \& Roland, G. (1995). Bank restructuring and soft budget constraints in financial transition. Journal of the Japanese and International Economies, 9, 354-375.

Berglöf, E., \& Roland, G. (1997). Soft budget constraints and credit crunches in financial transition. European Economic Review, 41, 807-817.

Blum, J. (1999). Do capital adequacy requirements reduce risks in banking. Journal of Banking and Finance, $23,755-771$.

Blum, J., \& Hellwig, M. (1995). The macroeconomic implications of capital adequacy requirements for banks. European Economic Review, 39, 739-749.

Cebula, R. J. (1994). The regional distribution of bank closings in the United States: An extension of the Amos analysis. Southern Economic Journal, 61, 202-208.

Cebula, R. J. (2010). Determinants of bank failures in the US revisited. Applied Economics Letters, 17, 1313-1317.

Chou, R. Y., \& Cebula, R. J. (1996). Determinants of geographic differentials in the savings and loan failure rate: A heteroskedastic TOBIT estimation. Journal of Financial Services Research, 10, 5-25.

Dewatripont, M., \& Maskin, E. (1995). Credit and efficiency in centralized and decentralized economies. Review of Economic Studies, 62, 541-555.

Du, J., \& Li, D. D. (2007). The soft budget constraint of banks. Journal of Comparative Economics, $35,108-135$.

Hyun, J.-S., \& Rhee, B.-K. (2011). Bank capital regulation and credit supply. Journal of Banking \& Finance, $35,323-330$.

Kornai, J. (1980). The Economics of Shortage. New York: North-Holland.

Litan, R. E. (1994). U.S. financial markets and institutions in the 1980s: A decade of turbulence. In M. Feldstein (Ed.), American Economic Policy in the 1980s (pp. 519-557). Chicago: University of Chicago Press for the National Bureau of Economic Research.

Luo, C. (2014). Questioning the soft budget constraint. Annals of Economics and Finance, 15, 205-214.

Mitchell, J. (2002). Banks' bad debts: policies, creditor passivity, and soft budget constraints. In A. Meyendorff \& A. Thakor (Eds.), Designing Financial Systems in Transition Economies (pp. 5-36). London: The MIT Press.

Peek, J., \& Rosengren, E. S. (2005). Unnatural selection: Perverse incentives and the misallocation of credit in Japan. American Economic Review, 95, 1144-1166.

Shleifer, A., \& Vishny, R. W. (1992). Liquidation values and debt capacity: A market equilibrium approach. Journal of Finance, 47, 1343-1366.

Vahabi, M. (2012). Soft budget constraints and predatory states. Review of Radical Political Economics, 44, $468-483$.

Vahabi, M. (2014). Soft budget constraint reconsidered. Bulletin of Economic Research, 66, 1-19.

Watanabe, W. (2010). Does a large loss of bank capital cause evergreening ? Evidence from Japan. Journal of the Japanese and International Economies, 24, 116-136. 